\title{
EMBRYOTOXICITY OF NINE SEED MORDANTS IN THE CHICK EMBRYO - THE CHEST METHOD
}

\author{
M. PETERKA ${ }^{1}$, M. TUČEK ${ }^{2}$, D. VESELÝ ${ }^{1}$ \\ ${ }^{1}$ Department of Teratology, Institute of Experimental Medicine, Academy of Sciences of the Czech \\ Republic, Prague \\ ${ }^{2}$ Regional Institute of Public Health, Plzeñ
}

Received May 3, 1996

Accepted September 24, 1996

\begin{abstract}
Peterka M., M. Tuček, D. Veselý: Embryotoxicity of Nine Seed Mordants in the Chick Embryo - the CHEST Method. Acta vet. Brno 1996, 65:213-217.

The seed mordants Agronal Super, which contains the organic mercury $(5.4 \%$ phenylmercurychloride), has appeared to induce poisoning and even death of many people and animals. Minimal single embryotoxic doses of Agronal Super were estimated in 2-4-day old chick embryos using the CHEST method and compared with the minimal embryotoxic doses of other 8 seed mordants without mercury. Minimal embryotoxic doses (the beginning of the embryotoxicity range) of Agronal Super were between 0.1-1.0 $\mu \mathrm{g} / \mathrm{embryo}$. The seed mordants without mercury appeared to be less toxic: The minimal embryotoxic doses of Baytan Combi, Baytan Universal, Fundasol, Quinolate and Wolfen Thiuram were between 1-10 $\mu$ g/embryo. Novozir and Sibutol had minimal embryotoxic doses within the range 10-100 $\mu \mathrm{g} / \mathrm{embryo}$. The least dangerous appeared the seed mordant Vincit, which produced no embryotoxic effect, even after administration of the highest doses (100 $\mu \mathrm{g} / \mathrm{embryo})$. Our results demonstrated the difference of several orders of magnitude between embryotoxic doses of Agronal Super and other 8 seed mordants. Replacement of seed mordants containing organic mercury (e.g. Agronal Super) by new ones with minimal or no embryotoxic effect (e.g. Vincit) is advisable.
\end{abstract}

Embryotoxicity, chick embryo, mercury, seed mordant, Agronal

Toxic effects of the mercury are known from old times. The development of chemistry entailed many new anorganic as well as organic mercury compositions. Some of them were or still are used as seed mordants. It has been reported that the organic mercury compounds used as seed mordants caused poisoning and even death of many people and animals (WHO 1976; Friberg et al. 1979; Tuček and Tuček 1981; Cibulka 1991).

Application of seed mordant substances containing alcylmercury has been already forbidden in most of industrial countries. Also in our country, the last stores of Agronal Super, whose effective component phenylmercurychloride contains $1.6-5.4 \%$ of mercury, have been already consumed. Approximately $85 \%$ of seed, before all wheat and barley, were preserved with Agronal Super. Each year, $10 \%$ from the total amount of manufactured mercury (i.e. 20 tons) was consumed for yearly Agronal production (900-1000 tons). The average usage of Agronal Super was 800 tons during the last years.

In the world as well as in the Czech Republic, a new generation of seed mordants without alcylmercury component started to be produced and applied. It is very important to know toxicity of the new seed mordants and use preferably only the least toxic ones. The chicken embryo assay has been successfully used for determination of the toxicity of various chemical substances such as drugs, food additives, mycotoxins and airborn particles (Nishigori et al. 1992; Verret et al. 1980; Veselý et al. 1992; Matsumoto 1988). Nishig ori et al. (1992) have developed a screening test using 15-day-old hen $s$ fertile eggs (Hen's fertile Egg Screening Test, HEST) for evaluation of activity and toxicity of drugs. In comparison with mammalian models, tests employing chick embryos are cheap and rapid. 
They also have an indisputable ethical advantage. The Chick Embryotoxicity Screening Test (CHEST) has been developed in our laboratory for embryotoxicity testing on the early stages of chick embryos (Jelínek 1982; Peterka et al. 1992).

In the present study, the CHEST method was used for embryotoxicity testing of seed mordants with and without mercury in order to estimate and compare their minimal embryotoxic doses (i.e. the beginning of the embryotoxicity range). The data on the minimal embryotoxic doses allowed us to rank the seed mordants according to their embryotoxicity risk.

\section{Materials and Methods}

The following seed mordants were tested: Agronal Super (phenylmercurychloride 5.4\% - Spolana Neratovice, Czech Republic), Baytan Combi 10.5 WS (imazalile 3\%, triadimenole 7.5\% - Cooperative farm Mír Práče, Czech Republic), Baytan Universal 19.5 WS (fuberidazole 2\%, imazalile 2.5\%, triadimenole 15\% - Cooperative farm Mír Práče, Czech Republic), Fundazol 50 WP (50\% benomyl - Chemolimpex Budapest, Hungaria), Novozir MN 80 (mancozeb 80\% - Duslo SaIa, Slovak Republic), Quinolate $15 \mathrm{~F}$ (oxine-Cu 15\%, fuberizadole 3\% - Chemical factories Kolín. Czech Republic), Sibutol WS 39.8 (bitertanole 37.5\%, fuberidazole 2.3\% - Cooperative farm Mír Práče, Czech Republic), Vincit F (flutriafole 2.5\%, thiabendazole 2.5\% - ICI Agrochemicals, Fernhurst, England), Wolfen Thiuram 85 (85\% thiram - VEB Berlin Chemie, Germany).

The Chick Embryotoxicity Screening Test - CHEST (Jelínek 1982; Peterka et al. 1992) was used. Cold fertile White Leghorn eggs purchased from the Farm Chlum (Prague) were placed horizontally in a forced-draft oven and incubated at $38^{\circ} \mathrm{C}$ and $40-60 \%$ relative humidity. Administration of a seed mordant was performed through a shell window using a calibrated glass micropipette. The single dose was injected either subgerminally on day 2 , or intraamniotically on days 3 and 4 . The seed mordants were diluted in distilled water and suspended by ultrasound. The injected volumes were either 3 or $10 \mu \mathrm{L}$ and contained increasing doses of the test substance, differing as a rule by one order of magnitude. After administration, the shell window was closed with a glass slide, sealed with paraffin, and the eggs were incubated henceforward without rotation.

The CHEST method includes two standard phases:

1. CHEST I. Increasing doses of seed mordants were singly administered, each dose to a group of 6 embryos within stages $10-11 \mathrm{HH}$ staging by Hamburger-Ha milt on (1951), corresponding to the incubation time about 40 hours. The length of the newly formed part of the trunk was measured by ocular micrometer after 24 hours of incubation following the injection. A significant shortening (one-side t-test was used) of the embryonic trunk length indicated that a dose interfered with the function of the caudal morphogenetic system building the caudal part of the embryonic trunk.

2. CHEST II. The last ineffective and the first two effective doses revealed by CHEST I were administered. Each of the three doses was given singly to a group of 10 embryos on each of days 2 (stages 11-14 HH), 3 (stages $17-20 \mathrm{HH}$ ) and 4 (stages $21-24 \mathrm{HH}$ ). The interval within days $2-4$ represents almost the whole critical period of organogenesis, when it is possible to induce structural malformations. The embryos were checked daily through a window and dead embryos were set aside. On day 8, the surviving fetuses were collected, weighted and inspected using a light stereomicroscope. Besides external examination of structural malformations, microdissection of the heart was routinely performed for detection of a ventricular septal defect and anomalies of great vessels. The embryotoxicity dose-response curve was established by summing up number of dead and living malformed specimens for each dose and day of administration, respectively (Pe terk a et al. 1986, 1992). The beginning of the embryotoxicity range was determined between the doses, where the embryotoxicity doseresponse curve crossed the nonspecific effect level (Peterka et al. 1992). The non specific effect level represents the maximal background frequency of malformed and dead embryos in the control groups that occur spontaneously and/or are induced by the experimental intervention itself. The upper limit of the nonspecific effect has been repeatedly calculated as $0.3(30 \%)$. This means that all values situated above this limit are statistically significant (Dix on and Massey 1969). The rough order estimation of the beginning of the embryotoxicity range for mammals was calculated according to the extrapolation formula (Jelínek 1982; Peterka et al. 1992).

\section{Results}

The values of the beginning of the embryotoxicity range in 9 seed mordants were estimated by CHEST II (Table 1). Agronal containing 5\% of phenylmercurychloride 
exhibited the highest embryotoxic effect (0.1-1.0 $\mu \mathrm{g})$. The second position was occupied by 5 seed mordants without mercury (Baytan Combi, Baytan Universal, Fundazol, Quinolate and Wolfen Thiurame). All these substances have the same value of the beginning of the embryotoxicity range (1.0-10.0 $\mu \mathrm{g})$ with differences inside one order of magnitude. Two seed mordants (Novozir and Sibutol), whose minimal embryotoxic doses were 10 to $100 \mu \mathrm{g}$, attained the $3 \mathrm{rd}$ position. The seed mordant Vincit did not produce any embryotoxic effect, even after administration of the highest dose $100 \mu \mathrm{g}$. The beginning of the embryotoxicity range in mammals ( $\mathrm{mg} / \mathrm{kg}$ of body mass) was estimated by theoretical recount (Table 1).

Table 1

The beginning of the embryotoxicity range in 9 seed mordants

\begin{tabular}{|l|c|c|}
\hline Substance & $\begin{array}{l}\text { CHEST II } \\
\mu \mathrm{g} / \mathrm{embryo}\end{array}$ & $\begin{array}{l}\text { Order estimate } \\
\text { for embryotoxicity } \\
\text { in mammals mg/kg }\end{array}$ \\
\hline Agronal Super & $0.1-1$ & $1-10$ \\
\hline Baytan Combi 10.5 WS & $1-10$ & $10-100$ \\
Baytan Univ.19.5 WS & $1-10$ & $10-100$ \\
Fundasol 50 WP & $1-10$ & $10-100$ \\
Quinolate 15 F & $1-10$ & $10-100$ \\
Wolfen Thiuram 85 & $1-10$ & $100-1000$ \\
\hline Novozir MN 80 & $10-100$ & $100-1000$ \\
\hline Sibutol Ws 39.8 & $10-100$ & $>1000$ \\
\hline Vincit F & $>100$ & \\
\hline
\end{tabular}

Table 2

Estimation of the embryotoxic effect 50\% (ED 50\%) - CHEST II

\begin{tabular}{|l|c|}
\hline Substance & doses $(\mu \mathrm{g} / \mathrm{embryo})$ \\
\hline Agronal Super & 3 \\
\hline Quinolate 15 F & 5 \\
Baytan Universal 19.5 WS & 7 \\
Wolfen Thiuram 85 & 10 \\
Fundasol 50 WP & 30 \\
Baytan Combi 10.5 WS & 40 \\
\hline Novozir MN 80 & 50 \\
\hline Sibutol Ws 39.8 & $100-200$ \\
Vincit F & $>100$ \\
\hline
\end{tabular}

The dose inducing increase of dead and/or malformed living embryos detected until day 8 to $50 \%$ of all injected specimens was indicated as ED 50 (Table 2). The order of all nine seed mordants remained the same even after ranking according to the ED 50 value. 


\section{Discussion}

Our results suggested that the seed mordant Agronal Super containing the organic mercury could be highly toxic not only for adult but also for developing organisms. It is alarming fact that the placenta represents unsufficient protection for developing embryo or fetus. Accordingly, anorganic as well as organic mercury compounds can be transmitted into the embryo or fetus with very high efficiency ( $\mathrm{Nak}$ ano 1985$)$. It is surprising, that different tissues of 87 dissected persons, that never had any professional contact with mercury compounds, comprise a considerable amount of mercury: liver, kidney, lung and pancreas tissues reaches 10-100 $\mu \mathrm{g} \mathrm{Hg} / \mathrm{kg}$ ( Tuček and Tuček 1981). Such an amount of the mercury in human tissues exceeds the Czech hygienic limit $10 \mu \mathrm{g} \mathrm{Hg} / \mathrm{kg}$. That is why all sources of mercury must bee reduced. Accordingly, the seed mordants containing organic mercury should be replaced by new ones with minimal or no toxic effect in eukaryotic organisms.

With regard to the wide spread employment of seed mordants in our environment, their possible embryotoxic potential should be taken into consideration, too. All of the tested seed mordants without mercury should be surely less embryotoxic than Agronal Super. Even among them however, big differences existed - several orders of magnitude - as their embryotoxicity is concerned. We have to respect an embryotoxic potency of a new seed mordant and choose the most safe one. Among the eight new seed mordants tested in the present study, Vincit appeared to exhibit no embryotoxic effect. Novozir and Sibutol may be also recomended, in spite of they are one order of magnitude more toxic than Vincit. The remaining five seed mordants were by two orders of magnitude more toxic than Vincit.

\section{Embryotoxicita 9 mořidel obilí na zárodku kuřete - metoda CHEST}

Mořidlo obilí Agronal Super, které obsahuje organickou rtut $(5,4 \%$ phenylmercurichloride) způsobila otravu a dokonce smrt u mnoha lidí a zviŕat. Agronal Super je postupně nahrazován mořidly, jež neobsahují toxickou rtut́. Zárodek kư̌ete ve věku 2-4 dny byl použit k odhadu jednorázové minimální embryotoxické dávky pro Agronal Super a tyto výsledky pak byly porovnány s minimálními embryotoxickými dávkami 8 mořidel obilí, která organickou rtut neobsahují.

Minimální embryotoxické dávky (začátek pásma embryotoxicity) pro Agronal Super byly stanoveny v rozmezí $0,1-1,0$ mg na 1 zárodek. Pět mořidel obilí (Baytan Combi, Baytan Universal, Fundasol, Quinolate a Wolfen Thiuram) bylo méně toxických minimální embryotoxické dávky byly v rozmezí mezi 1.0-10 $\mu \mathrm{g}$ na 1 zárodek. Dvě další mořidla (Novozir a Sibutol) vykazovala minimální embryotoxické dávky v pásmu mezi 10-100 $\mu \mathrm{g}$ na 1 zárodek. Nejméně embryotoxickým mořidlem obilí byl Vincit, který nevykazoval embryotoxický efekt ani v nejvyšších testovaných dávkách $100 \mu \mathrm{g}$ na 1 zárodek. Získané výsledky testování ukazují, že rozdíly v embryotoxických dávkách mezi Agronalem Super a 8 mořidly obilí jsou několik dávkových řádů. Nahrazení toxického mořidla Agronal Super některým z novějších preparátů $s$ minimálním nebo nulovým embryotoxickým efektem je žádoucí.

\section{References}

CIBULKA, J. 1991: Movement of lead, cadmium and mercury in the biosphere. Academia, Praha, Czech Republic DIXON, W. J., MASSEY, F. J. 1969: Introduction to statistical analysis. McGraw-Hill Book Co, New York 
FRIBERG, L., NORDBERG, C. F., VOUK, V. B. 1979: Handbook on the Toxicology of Metals. Elsevier, Amsterdam

HAMBURGER, V., HAMILTON, H. L. 1951: A series of normal stages in the development of the chick embryo. J. Morph. 88:49-92

JELINEK, R. 1982: Use of chick embryo in screening for embryotoxicity. Teratogen. Carcinogen. Mutagen. 2:255261

MATSUMOTO, H. 1988: Toxicity to chicken embryos of organic extracts from airborne particulates separated into five sizes. Bull. Environ. Contam. Toxicol. 41:44-49

NAKANO, A. 1985: A study on the placental transfer on mercury in pregnant woman. Jpn. J. Hyg. 40:685-694

NISHIGORI, H., MIZUMURA, M., IWATSURU, M. 1992:The hen's fertile egg screening test (HEST): A comparison between the acute toxicity for chick embryos and rodent of 20 drugs. Cell Biol. Toxicol. 4:255265

PETERKA, M., HAVRÁNEK, T. JELINEK, R. 1986:Dose-response relationship in chick embryos exposed to embryotoxic agents. Folia Morphol. 34:69-77

PETERKA, M., JELfNEK, R., PAVLIK, A. 1992:Embryotoxicity of 25 psychotropic drugs: A study using CHEST. Reproductive Toxicol. 6:367-374

TUČEK, J., TUČEK, M. 1981:Contribution to the problem of environmental contamination with mercury. J. Hyg. Epid. Microb. Immunol. 25:354-363

VERRET, M. J., SCOTT, W. F., REYNALDO, E. F., ALTERMAN, E. K. THOMAS, C. A. 1980: Toxicity and teratogenicity of food additive chemicals in the developing chicken embryo. Toxicol. Appl. Pharmacol. 56:265273

VESELÝ, D., VESELÁ, D., JELINEK, R. 1992: Embryotoxicity of T-2 toxin and secalonic acid in embryonic chick varies with the site of administration. Teratology 46:131-136

WHO: Environmental Health Criteria. 1. Mercury. Geneva, 1971

Address for correspondence:

MUDr. Miroslav Peterka, CSc.

Department of Teratology

Institute of Experimental Medicine

Academy of Sciences of the Czech Republic

Vídeňská 1083

CZ-14220 Prague 4

Czech Republic

Tel.: (02) 4752232 